\title{
VIEWPOINT
}

\section{The tracheal tube: gateway to ventilator-associated pneumonia}

\author{
Parjam S Zolfaghari** and Duncan LA Wyncoll²
}

\begin{abstract}
Ventilator-associated pneumonia (VAP) is a major healthcare-associated complication with considerable attributable morbidity, mortality and cost. Inherent design flaws in the standard high-volume lowpressure cuffed tracheal tubes form a major part of the pathogenic mechanism causing VAP. The formation of folds in the inflated cuff leads to microaspiration of pooled oropharyngeal secretions into the trachea, and biofilm formation on the inner surface of the tracheal tube helps to maintain bacterial colonization of the lower airways. Improved design of tracheal tubes with new cuff material and shape have reduced the size and number of these folds, which together with the addition of suction ports above the cuff to drain pooled subglottic secretions leads to reduced aspiration of oropharyngeal secretions. Furthermore, coating tracheal tubes with antibacterial agents reduces biofilm formation and the incidence of VAP. In this Viewpoint article we explore the published data supporting the new tracheal tubes and their potential contribution to VAP prevention strategies. We also propose that it may now be against good medical practice to continue to use a'standard cuffed tube' given what is already known, and the weight of evidence supporting the use of newer tube designs.
\end{abstract}

\section{Introduction}

Ventilator-associated pneumonia (VAP) is defined as pneumonia occurring in a mechanically ventilated patient after 48 hours of endotracheal intubation [1]. Despite significant advances in managing intubated patients, VAP remains a common and occasionally fatal complication in the ICU [2]. A systematic review of published data since

\footnotetext{
*Correspondence: parjamz@yahoo.co.uk

'London Deanery, Guy's and St Thomas' NHS Trust, Lambeth Palace Road, London SE1 7EH, UK

Full list of author information is available at the end of the article
}

1990 showed the incidence of VAP to be 10 to $20 \%$, with a possible two-fold increase in mortality attributable to VAP [3]. The ICU length of stay was also significantly increased by a mean of 6.1 days with an attributable cost of $\$ 10,019$ per case [3]. A recent Canadian study estimated an additional 4.3 ICU days attributable to VAP, occupying $2 \%$ of all ICU days and an estimated national cost of CAN\$43 million per year [4]. Similar findings were reported by a North American study with increased unadjusted ICU length of stay and mortality in patients with VAP (50\% mortality in VAP patients versus $34 \%$ in non-VAP) with an estimated $\$ 11,897$ attributable cost [5]. Furthermore, the burden of VAP takes up a significant portion of antibiotic dispensing in the ICU [6] and may well be a contributor to the development of multiresistant bacteria [7].

Importantly, many units are recently reporting a reduction in VAP incidence following implementation of various prevention measures, as well as programs that increase compliance with such care bundles [8-10].

\section{Pathogenesis}

The pathogenesis of VAP mainly stems from the introduction of microbial pathogens by microaspiration past the tracheal tube cuff and into the lower respiratory tract (Figure 1). Subsequent colonization and overwhelming of the host mechanical, humoral and cellular defence mechanisms lead to the development of VAP [11]. The tracheal tube forms the essential first part of this mechanistic pathway by breeching the anatomic barriers formed by the glottis and larynx. Suppression of the cough reflex as a result of sedation further hampers natural reflexes [2]. The oropharynx, nasal sinuses and the stomach have been proposed as potential reservoirs of infective material [11]. Furthermore, bacterial biofilm formation on the inner aspect of the tracheal tube is another potential portal of bacteria [12]. But perhaps more importantly, this biofilm formation, which takes place within days of intubation, functions to maintain bacterial colonization of the trachea [13]. The biofilm is inaccessible to antibiotic therapy unless aerosolised, which likely reduces bacterial shedding, but does not lead to full eradication and may even promote antibiotic 


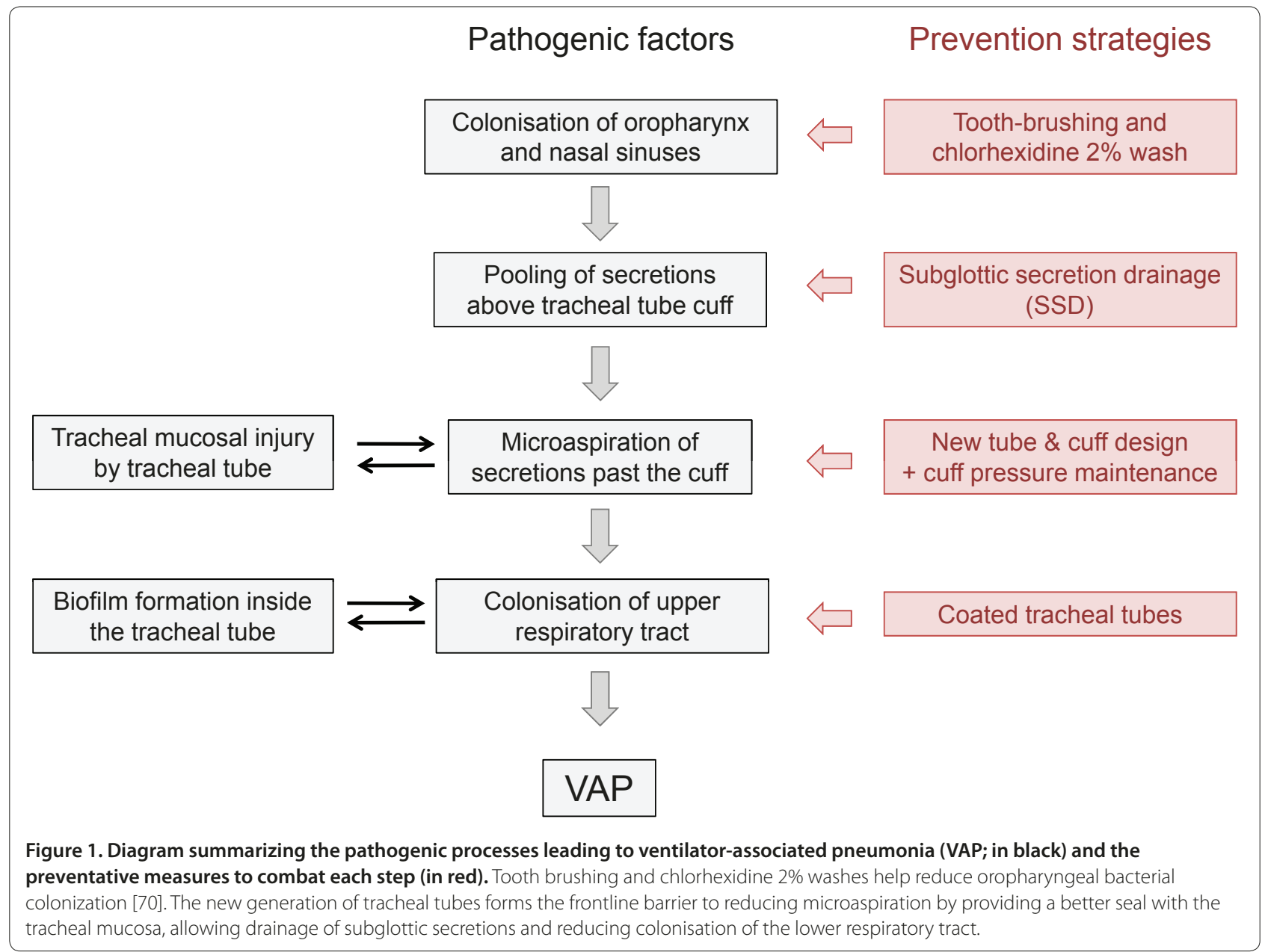

resistance [14]. The fact that the NASCENT trial, using a silver-coated tracheal tube, showed a significant reduction in microbiologically diagnosed VAP suggests that intraluminal biofilm and the intratracheal route of infection contribute significantly to the aetiology of VAP [15].

This article explores the contribution of the tracheal tube to the development of VAP and looks at how the emergence of new designs may help prevent this complication. A question is posed: is it good medical practice to continue to use a 'standard cuffed tube' given what is already known?

\section{The contribution of the tracheal tube cuff}

The main function of the tracheal tube cuff is to produce a seal between the tube and the tracheal mucosa in order to allow the institution of positive pressure ventilation. It has become apparent, however, that pooling and leakage around the endotracheal tube cuff leads to aspiration of contaminated oropharyngeal secretions, stomach contents and bacteria into the trachea and the lower respiratory tract [16]. This is supported by the finding that persistent intra-cuff pressures of $<20 \mathrm{cmH}_{2} \mathrm{O}$ in intubated patients are independently associated with pneumonia [17]. Furthermore, frequent microaspiration of stomach contents as evidenced by the presence of pepsin in sequential tracheal aspirates is an independent predictor of pneumonia in intubated patients [18]. These findings highlight the importance of adequate sealing of the lower respiratory tract from soiling by oropharyngeal secretions.

Some small studies have looked at the use of automated devices to control cuff pressures but have produced varying results. In an 'underpowered' randomised controlled trial where cuff pressures were maintained either by an automatic device at 25 to $30 \mathrm{cmH}_{2} \mathrm{O}$, or 8-hourly nurse-adjusted cuff pressures, no difference in the incidence of VAP was observed [19]. Conversely, a more recent proof of concept study showed reduced pepsin and micro-aspiration in the tracheal samples and lower microbiologically confirmed VAP in patients where an automated device was used to maintain cuff pressures [20].

Interestingly, despite correctly pressurised cuffs in commonly used standard high-volume low-pressure 
tubes, microaspiration often takes place [21-23]. This stems from the basically flawed design of these cuffs. The diameter of the fully inflated cuff is up to twice as large as the diameter of the tracheal lumen, so that once inflated to the correct pressure in the trachea, these cuffs remain only partially inflated and result in the formation of folds along the cuff that then channel oropharyngeal secretions into the trachea [21]. Bench studies have clearly demonstrated these findings (Figure 2) and identified major design features that influence the size of these leaky folds and channels.

\section{Excess cuff material and shape of the cuff}

Newer tracheal tube cuff designs such as the Lo-Trach ${ }^{\text {Tw }}$ (Intravent) low-volume low-pressure cuff and the Microcuff $^{\text {sw }}$ tube (Kimberly-Clark) have shown promising results with significant reduction in leakage of fluid placed above the cuffs [24-26]. The Microcuff tube has $^{\text {ma }}$ an elongated cylindrical-shaped cuff that results in a fully inflated cuff in situ with minimal excess cuff material at acceptable intracuff pressures of 20 to $30 \mathrm{cmH}_{2} \mathrm{O}$. The fully inflated cuff leads to limited or even absence of channel formation and the shape of the cuff results in a larger surface area in contact with the trachea. Microaspiration of blue dye placed above the cuff (as demonstrated by bronchoscopy) was also shown to be reduced and delayed in patients intubated with the Mallinckrodt/ Covidien SealGuard ${ }^{\mathrm{Tm}}$ tube with an inverted pear-shaped (conical) cuff [27]. This pear-shaped design was first described in 1999 by Young and Blunt [28], and subsequently shown to provide better sealing properties across a wider range of tracheal diameters when compared to the cylindrical-shaped cuff [29].

\section{Tracheal tube cuff material}

A major advance in the tracheal tube cuff design has been the introduction of thinner ( $7 \mu \mathrm{m}$ thick) polyurethane (PU) material [29]. These cuffs have consistently been shown to form narrower folds/channels with reduced leakage than tubes with thicker $(50 \mu \mathrm{m})$ polyvinyl chloride (PVC) cuffs $[21,25,30]$. Clinical studies have also confirmed reduced leakage of subglottic material [27], reduced pepsin levels in tracheal secretions [31], and lower rates of nosocomial post-operative pneumonia in patients following cardiac surgery randomised to endotracheal tubes with cuffs made from PU [32]. A retrospective analysis of intubated patients following the introduction of tracheal tubes with PU cuffs showed a reduction in VAP from 5.3 to 2.8 per 1,000 ventilator days [33]. In an elegant in vitro study of six commercially available tracheal tubes, Zanella and colleagues [30] showed that all cuffs made from PVC (be they conical or cylindrical in shape) demonstrated significant leakage over a 24-hour period, except when a positive

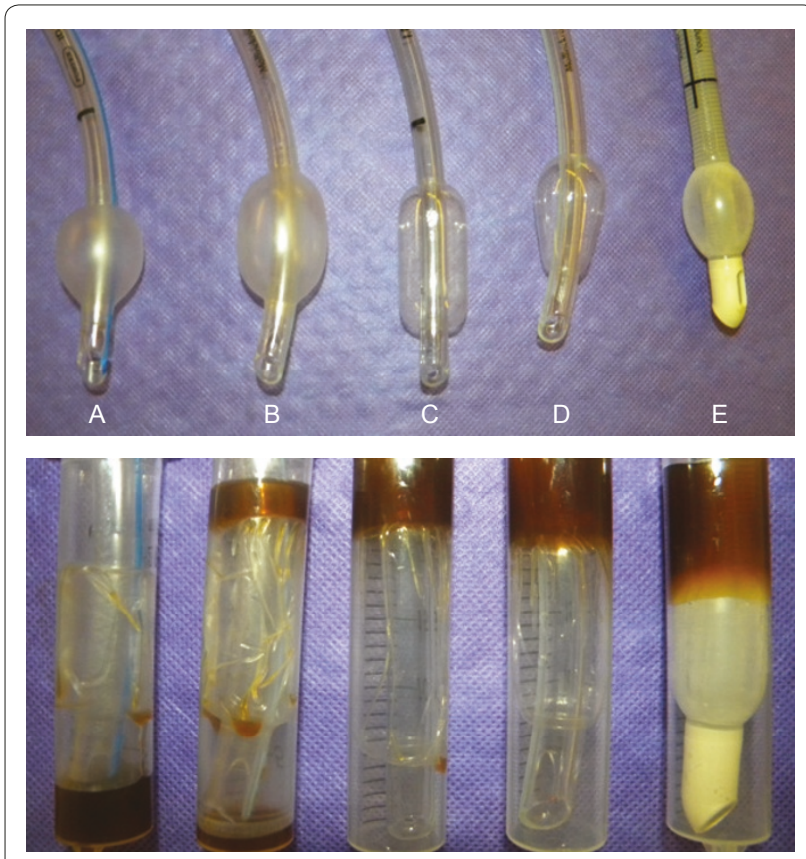

Figure 2. Photograph of various bench tested tracheal tubes of different designs showing the internal channels created and the leak of liquid material past the cuff. Tube cuffs $A$ and $B$ are made from polyvinyl chloride, and cuffs $C$ and $D$ with thin polyurethane ( $C$ has an elongated cylindrical shape and $D$ is a tapered cuff design). Tube $\mathrm{E}$ is the LoTrach ${ }^{\mathrm{TM}} \mathrm{ET}$ tube. (Photograph courtesy of Dr Peter Young, Kings Lynn, UK.)

end-expiratory pressure (PEEP) of $15 \mathrm{cmH}_{2} \mathrm{O}$ was applied in addition. On the other hand, double-layered cuffs made of Guayule-latex and PU cuffs provided significantly improved performances with minimal leakage at zero PEEP and none at $5 \mathrm{cmH}_{2} \mathrm{O}$. Interestingly, there was no difference in performance between the cylindrical and conically shaped cuffs made from PU (Microcuff $^{\text {max }}$, cylindrical versus Mallinckrodt/Covidien SealGuard ${ }^{\mathrm{mm}}$, conical).

\section{Subglottic secretion drainage and ventilator- associated pneumonia}

Removal of oropharyngeal secretions that have pooled above the tracheal tube cuff by subglottic secretion drainage (SSD) further reduces microaspiration [34-37] (Figure 3 ). Specially designed tracheal tubes are widely available, with a separate lumen or lumens that open above the cuff and allow intermittent or continuous drainage of the pooled secretions. In 2005, a metaanalysis examining five prospective studies using SSD showed a $50 \%$ reduction in the incidence of pneumonia in patients randomised to SSD [38]. This effect was more pronounced in those who were intubated for more than 72 hours and for early onset VAP. A reduction in the length of mechanical ventilation and ICU stay (2 and 


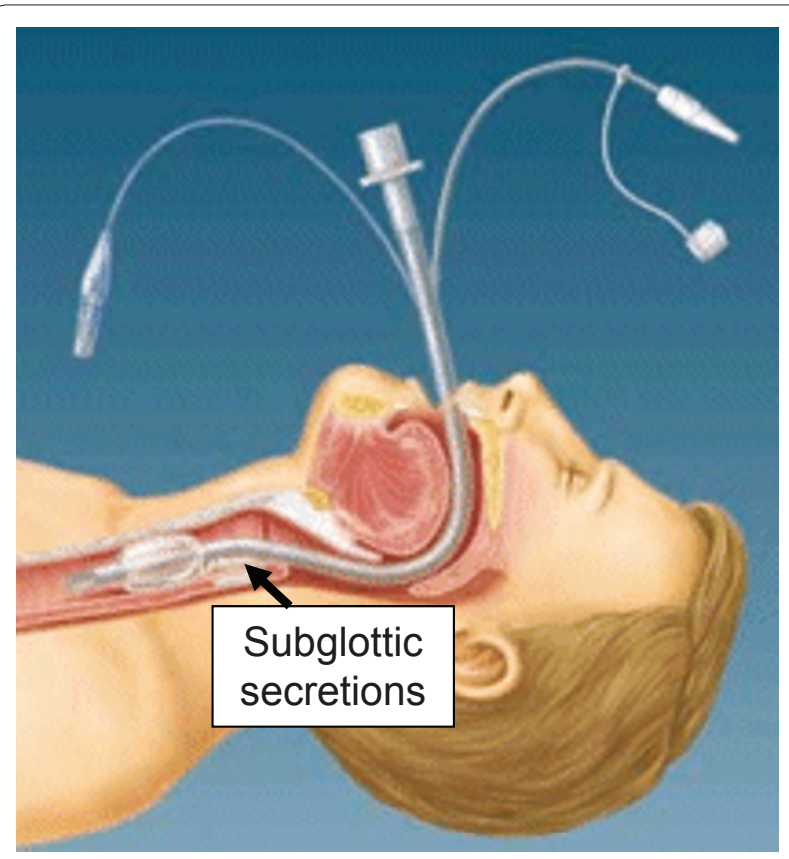

Figure 3. Endotracheal tube with subglottic suction port placed posteriorly and above the cuff for drainage of pooled secretion in the semi-recumbent position. Intermittent suction is applied to avoid ischaemic injury to the tracheal mucosa.

3 days, respectively) makes this a favourable intervention, and has now been included in many national VAP prevention bundles [39]. Further convincing evidence has also been published since this 2005 meta-analysis $[34,36,37]$.

However, the uptake of SSD into clinical practice has been slow [40], and this is likely because of (i) conflicting clinical trial evidence, (ii) safety concerns surrounding laryngeal/tracheal damage caused by the stiffer nature of these tubes, (iii) suction damage to the tracheal mucosa, (iv) the higher cost of the tubes, and (v) the fact that the studies often only show that early VAP is reduced. Of nine prospective, randomised controlled studies of SSD, six did not look at adverse effects of SSD, two reported no adverse events and one reported a significant increase in the risk of laryngeal oedema requiring re-intubation in patients intubated with an SSD tube [13,41]. Furthermore, Dragoumanis and colleagues [42] described herniation of tracheal mucosa into the dorsal SSD suction port of the first generation $\mathrm{Hi}-\mathrm{Lo}^{\circ}$ Evac endotracheal tube (Hi-Lo Evac, Mallinckrodt, Athlone, Ireland), resulting in failure of subglottic suction and the risk of mucosal injury due to tissue ischaemia. Of concern also is the fact that in sheep, significant tracheal mucosal injury has been observed with continuous aspiration of subglottic secretions [43].

These observations have encouraged the development of second and third generation tube designs, which have overcome some of these concerns. In some tubes the position of the SSD suction port has been placed adjacent to the tracheal tube cuff, lifting its opening away from the tracheal mucosa. Also, improved cuff designs that produce a better tracheal seal (tapered/conical PU or lowvolume controlled-pressure cuffs) have allowed hourly intermittent suctioning, instead of continuous suction [37]. Avoiding continuous suctioning strongly suggests that ischaemic lesions of the posterior tracheal wall can now be avoided. The LoTrach ${ }^{\text {Tx }}$ tube has further addressed these concerns by incorporating three subglottic suction ports adjacent to the tracheal tube cuff, making subglottic suctioning more efficient and less traumatic. Furthermore, its flexible design conforms to the shape of the upper airway, potentially reducing laryngeal injury [24].

In order to accommodate the SSD channel into the wall of the tracheal tube, the outer diameter of the tube in some of the designs has had to be enlarged by approximately $1 \mathrm{~mm}$ on average and some designs are slightly stiffer. This needs to be taken into consideration when sizing these tracheal tubes in order to avoid laryngeal injuries, and is a potential area for future refinement in design.

\section{Tracheal tube biofilm management}

Microbial biofilms are present on the luminal surface of endotracheal tubes of all patients ventilated in the ICU and form within hours of tracheal intubation, becoming abundant at 96 hours $[12,44,45]$. Whilst the exact sequence of tube colonisation and infection is unclear, it is thought that the microbial biofilm may act as a reservoir of pathogens causing recurrent infections [45]. Adair and colleagues [12] showed that $70 \%$ of patients with VAP had the identical pathogen isolated from their tracheal tube and lower respiratory tract. Furthermore, biofilms are associated with developing microbial bacterial resistance [46].

Endotracheal tubes coated with anti-microbial silver hygrogel showed delayed and reduced bacterial colonisation in a mechanically ventilated animal model [47]. In one of the largest multi-centre prospective studies of VAP prevention (NASCENT study), Kollef and colleagues [15] compared rates of VAP in 2,003 patients randomised to intubation with either a silver-coated tube (Agento IC, CR Bard Inc., Covington, GA, USA) or the Hi-Lo Endotracheal Tube (Mallinckrodt, St Louis, MO, USA). This study showed a statistically significant relative risk reduction of $36 \%$ in the occurrence of VAP in patients intubated with silver-coated tubes, but failed to show a reduction in length of mechanical ventilation, ICU stay or mortality. Interestingly, the VAP rates in this study were lower than previously quoted rates (5 to $10 \%$ versus the 10 to $20 \%$ in other studies frequently quoted). 


\section{Tracheotomies and ventilator-associated pneumonia}

Another frequently debated point is the influence of the timing of tracheotomy on the development of VAP. While Rumbak and colleagues [48] showed a significant reduction in the development of VAP with early tracheotomy (within 48 hours of mechanical ventilation) versus delayed tracheotomy (after 14 to 16 days), a later but larger multicentre study showed no difference in the rate of pneumonia in patients that underwent early tracheotomy versus patients who had more prolonged endotracheal intubation [49]. The largest multicentre study on this question showed no difference in the incidence of VAP with early tracheotomy (after 6 to 8 days of tracheal intubation) versus later tracheotomy (after 13 to 15 days) [50]. One interpretation of these observations is that while a patient has any artificial cuffed airway in place (whether endotracheal or tracheostomy tube), this predisposes to some degree of microaspiration and biofilm formation on the inner lumen, which increases the risk for VAP. However, many of the novel design features already mentioned are also now being incorporated into new tracheostomy tubes.

\section{Other strategies}

It is clear that reducing the incidence of VAP requires new strategies incorporating guidelines, resources, education and leadership [51,52]. Patient positioning, sedation holds, adequate and frequent oral hygiene, SSD, maintenance of cuff pressures and guidelines on stress ulcer prophylaxis are listed in a high impact care bundle to prevent VAP that has recently been published [39]. The integration of new and proven technology into this strategy will further improve its success. Current evidence highlighting the role of tracheal tubes in the pathogenic processes leading to the development of VAP may be ethically difficult to ignore. The newer tracheal tubes with tapered or cylindrical cuffs made from thin PU material and incorporating subglottic ports for intermittent suction of subglottic secretions should be an addition to this VAP bundle. Furthermore, automating cuff pressures using devices such as the disposable Portex PressureEasy ${ }^{\circ}$ cuff controller or the Venner ${ }^{\mathrm{mm}}$ PneuX PY ${ }^{\mathrm{mm}}$, comprising the Venner tracheal seal monitor device in conjunction with the LoTrach ${ }^{\mathrm{Tm}}$ ET Tube and LoTrach ${ }^{\mathrm{Tm}}$ $\mathrm{T}$ Tube, would limit exposure to low $\left(<20 \mathrm{cmH}_{2} \mathrm{O}\right)$ and high $\left(>30 \mathrm{cmH}_{2} \mathrm{O}\right)$ cuff pressures (that is, by continuous monitoring and maintaining of cuff pressure). Interestingly, in a study discussed earlier, using a constant cuff pressure controller device failed to show statistically significant reduction in VAP when compared to an 8-hourly nurse monitored method (22\% VAP in intervention group versus $29 \%$ in control group) [19]. However, the investigators used the leaky PVC high-volume low-pressure cuffed tubes for both groups, and highlight the point that using single interventions to reduce VAP is unlikely to be as successful as multiple interventions [53].

\section{Attributable mortality and ventilator-associated pneumonia}

Some clinicians remain concerned about the lack of effect on mortality in the published studies of VAP reduction interventions. Mortality is clearly the hardest end-point for clinical trials in the critically ill, but softer outcomes such as VAP should not be ignored [54]. It is important to distinguish the consequences of VAP from the progression of an underlying illness, and a key variable is the attributable mortality of developing VAP. The literature is not clear in answering this question, since it may well depend on the severity of underlying disease and acute respiratory failure as a result of pneumonia $[55,56]$, the case-mix of the population [57], the adequacy of initial empiric treatment [58], and the infecting agent [59]. Methodological differences, such as variables and covariates used to match control patients in the various studies, add to this uncertainty [3].

The attributable mortality of VAP is widely quoted as 0 to $36 \%$ [60-63]. By way of illustration, let us consider a hypothetical VAP trial involving 800 patients, and a proposed new intervention that reduces VAP by $50 \%$. In this population the control arm event rate (VAP) is about $20 \%$, and the 28 -day mortality is also about $20 \%$. If the trial showed that VAP was reduced to $10 \%$ in the intervention arm (a 50\% reduction), and if it was assumed that the attributable mortality due to VAP is about $10 \%$, then at very best mortality could only be reduced by a statistically non-significant (but clinically important) four patients. Hence the reason why so many of the current studies are not powered for mortality.

\section{Should the newer tubes be used for all intubated patients admitted to the ICU?}

The incidence of VAP increases with length of mechanical ventilation $[64,65]$, and the evidence presented above points towards more benefit being gained by patients intubated for prolonged periods [15,38]. Various tools have been proposed to predict length of mechanical ventilation, but these are only applicable at 24 to 48 hours following institution of mechanical ventilation [66,67]. It could therefore be argued as reasonable to intubate all patients admitted to the ICU who are expected to be intubated for longer than 24/48 hours with a newer generation tracheal tube.

\section{Can we justify the higher cost of the newer tubes?}

When compared to the old generation (leaky) tubes without subglottic suction, which cost about $\$ 2$ each, and considering that each new case of VAP leads to an 
increased estimated cost of approximately $\$ 5,000$ to $\$ 26,000$ [5], then it would be financially beneficial to pay a lot more for the 'interface' (that is, the tube) between the ventilator and the patient - an 'interface' that can potentially contribute to or prevent VAP. A cost-analysis performed by Shorr and colleagues [68] found a $\$ 12,840$ reduction in hospital costs per single case of VAP prevented as a result of introducing $\$ 90$ silver-coated tubes compared to using standard $\$ 2$ non-coated tubes, making this a very financially viable intervention. In fact, the break-even cost of the silver-coated tubes was calculated to be $\$ 388$. Even 'back of the envelope' conservative calculations that assume the cost of a VAP to be just $\$ 5,000$ would support an investment of $\$ 49$ per patient in a new intervention if it merely reduces the rate of VAP by just $1 \%$ absolute!

\section{Conclusion}

In a recent editorial, Valles, Blanch and Respiratorias [69] applied Sutton's law to interventions that prevent VAP. Willy Sutton was a prolific bank robber, having stolen $\$ 2$ million over his career. When asked by a reporter why he continued to rob banks, he replied, 'Because that is where the money is'. Application of Sutton's law - 'Go where the money is' - to the paradigm of VAP prevention strongly favours multi-faceted strategies aimed at reducing aspiration of oropharyngeal secretions. With the increasing weight of evidence pointing at the role of the tracheal tube design and maintenance of adequate cuff pressures, is it really good medical practice to continue to use 'standard cuffed tubes'?

\section{Abbreviations}

PEEP, positive end-expiratory pressure; PU, polyurethane; PVC, polyvinyl chloride; SSD, subglottic secretion drainage; VAP, ventilator-associated pneumonia.

\section{Competing interests}

PSZ has no competing interests. In the past 3 years, DW has acted as a paid consultant or given lectures on VAP for Covidien, Kimberly-Clark and Bard.

\section{Acknowledgements}

We would like to thank Dr Peter Young for advice in writing the manuscript and for supplying the photographs displayed in Figure 2.

\section{Author details}

'London Deanery, Guy's and St Thomas' NHS Trust, Lambeth Palace Road, London SE1 7EH, UK. 'Guy's and St Thomas' NHS Trust, Lambeth Palace Road, London SE1 7EH, UK.

Published: 29 September 2011

\section{References}

1. Kollef $\mathrm{MH}$ : What is ventilator-associated pneumonia and why is it important? Respir Care 2005, 50:714-721; discussion 721-714

2. Chastre J, Fagon J-Y: Ventilator-associated pneumonia. Am J Respir Crit Care Med 2002, 165:867-903.

3. Safdar N, Dezfulian C, Collard HR, Saint S: Clinical and economic consequences of ventilator-associated pneumonia: a systematic review. Crit Care Med 2005, 33:2184-2193.

4. Muscedere JG, Martin CM, Heyland DK: The impact of ventilator-associated pneumonia on the Canadian health care system. J Crit Care 2008, 23:5-10.

5. Warren DK, Shukla SJ, Olsen MA, Kollef MH, Hollenbeak CS, Cox MJ, Cohen MM, Fraser VJ: Outcome and attributable cost of ventilator-associated pneumonia among intensive care unit patients in a suburban medical center. Crit Care Med 2003, 31:1312-1317.

6. Bergmans DC, Bonten MJ, Gaillard CA, van Tiel FH, van der Geest S, de Leeuw PW, Stobberingh EE: Indications for antibiotic use in ICU patients: a oneyear prospective surveillance. J Antimicrob Chemother 1997, 39:527-535.

7. Klompas M: Prevention of ventilator-associated pneumonia. Expert Rev Anti Infect Ther 2010, 8:791-800.

8. Hawe CS, Ellis KS, Cairns CJS, Longmate A: Reduction of ventilatorassociated pneumonia: active versus passive guideline implementation. Intensive Care Med 2009, 35:1180-1186.

9. Bird D, Zambuto A, O'Donnell C, Silva J, Korn C, Burke R, Burke P, Agarwal S: Adherence to ventilator-associated pneumonia bundle and incidence of ventilator-associated pneumonia in the surgical intensive care unit. Arch Surg 2010, 145:465-470.

10. Bouadma L, Mourvillier B, Deiler V, Le Corre B, Lolom I, Régnier B, Wolff M, Lucet J-C: A multifaceted program to prevent ventilator-associated pneumonia: Impact on compliance with preventive measures*. Crit Care Med 2010, 38:789-796.

11. Niederman MS: The clinical diagnosis of ventilator-associated pneumonia. Respir Care 2005, 50:788-796; discussion 807-712.

12. Adair CG, Gorman SP, Feron BM, Byers LM, Jones DS, Goldsmith CE, Moore JE, Kerr JR, Curran MD, Hogg G, Webb CH, McCarthy GJ, Milligan KR: Implications of endotracheal tube biofilm for ventilator-associated pneumonia. Intensive Care Med 1999, 25:1072-1076.

13. Deem S, Treggiari MM: New endotracheal tubes designed to prevent ventilator-associated pneumonia: do they make a difference? Respir Care 2010, 55:1046-1055.

14. Stewart PS, Costerton JW: Antibiotic resistance of bacteria in biofilms Lancet 2001, 358:135-138

15. Kollef MH, Afessa B, Anzueto A, Veremakis C, Kerr KM, Margolis BD, Craven DE, Roberts PR, Arroliga AC, Hubmayr RD, Restrepo MI, Auger WR, Schinner R; NASCENT Investigation Group: Silver-coated endotracheal tubes and incidence of ventilator-associated pneumonia: the NASCENT randomized trial. JAMA 2008, 300:805-813.

16. Craven DE, Hjalmarson Kl: Ventilator-associated tracheobronchitis and pneumonia: thinking outside the box. Clin Infect Dis 2010, 51 Suppl 1:S59-66.

17. Rello J, Soñora R, Jubert P, Artigas A, Rué M, Vallés J: Pneumonia in intubated patients: role of respiratory airway care. Am J Respir Crit Care Med 1996, 154:111-115.

18. Metheny NA, Clouse RE, Chang Y-H, Stewart BJ, Oliver DA, Kollef MH: Tracheobronchial aspiration of gastric contents in critically ill tube-fed patients: frequency, outcomes, and risk factors. Crit Care Med 2006, 34:1007-1015.

19. Valencia M, Ferrer M, Farre R, Navajas D, Badia JR, Nicolas JM, Torres A: Automatic control of tracheal tube cuff pressure in ventilated patients in semirecumbent position: a randomized trial. Crit Care Med 2007, 35:1543-1549.

20. Nseir S, Zerimech F, Fournier C, Lubret R, Ramon P, Durocher A, Balduyck M: Continuous control of tracheal cuff pressure and microaspiration of gastric contents: a randomized controlled study. Crit Care 2011, 15(Suppl 1):158.

21. Seegobin RD, van Hasselt GL: Aspiration beyond endotracheal cuffs. Can Anaesth Soc J 1986, 33:273-279.

22. Young PJ, Rollinson M, Downward G, Henderson S: Leakage of fluid past the tracheal tube cuff in a benchtop model. Br J Anaesth 1997, 78:557-562.

23. Asai T, Shingu K: Leakage of fluid around high-volume, low-pressure cuffs apparatus A comparison of four tracheal tubes. Anaesthesia 2001, 56:38-42.

24. Young PJ, Pakeerathan S, Blunt MC, Subramanya S: A low-volume, lowpressure tracheal tube cuff reduces pulmonary aspiration. Crit Care Med 2006, 34:632-639.

25. Dullenkopf A, Gerber A, Weiss M: Fluid leakage past tracheal tube cuffs: evaluation of the new Microcuff endotracheal tube. Intensive Care Med 2003, 29:1849-1853.

26. Pitts R, Fisher D, Sulemanji D, Kratohvil J, Jiang Y, Kacmarek R: Variables affecting leakage past endotracheal tube cuffs: a bench study. Intensive Care Med 2010, 36:2066-2073.

27. Lucangelo U, Zin WA, Antonaglia V, Petrucci L, Viviani M, Buscema G, Borelli M, 
Berlot G: Effect of positive expiratory pressure and type of tracheal cuff on the incidence of aspiration in mechanically ventilated patients in an intensive care unit. Crit Care Med 2008, 36:409-413.

28. Young PJ, Blunt MC: Improving the shape and compliance characteristics of a high-volume, low-pressure cuff improves tracheal seal. Br J Anaesth 1999, 83:887-889.

29. Dave MH, Frotzler A, Spielmann N, Madjdpour C, Weiss M: Effect of tracheal tube cuff shape on fluid leakage across the cuff: an in vitro study. $B r J$ Anaesth 2010, 105:538-543.

30. Zanella A, Scaravilli V, Isgrò S, Milan M, Cressoni M, Patroniti N, Fumagalli R, Pesenti A: Fluid leakage across tracheal tube cuff, effect of different cuff material, shape, and positive expiratory pressure: a bench-top study. Intensive Care Med 2011, 37:343-347.

31. Nseir S, Zerimech F, De Jonckheere J, Alves I, Balduyck M, Durocher A: Impact of polyurethane on variations in tracheal cuff pressure in critically ill patients: a prospective observational study. Intensive Care Med 2010, 36:1156-1163.

32. Poelaert J, Depuydt P, De Wolf A, Van de Velde S, Herck I, Blot S: Polyurethane cuffed endotracheal tubes to prevent early postoperative pneumonia after cardiac surgery: a pilot study. J Thorac Cardiovasc Surg 2008, 135:771-776.

33. Miller MA, Arndt JL, Konkle MA, Chenoweth CE, I washyna TJ, Flaherty KR, Hyzy RC: A polyurethane cuffed endotracheal tube is associated with decreased rates of ventilator-associated pneumonia. J Crit Care 2011, 26:280-286.

34. Lorente L, Lecuona M, Jiménez A, Mora ML, Sierra A: Influence of an endotracheal tube with polyurethane cuff and subglottic secretion drainage on pneumonia. Am J Respir Crit Care Med 2007, 176:1079-1083.

35. Bouza E, Burillo A: Advances in the prevention and management of ventilator-associated pneumonia. Curr Opin Infect Dis 2009, 22:345-351.

36. Bouza E, Pérez MJ, Muñoz P, Rincón C, Barrio JM, Hortal J: Continuous aspiration of subglottic secretions in the prevention of ventilatorassociated pneumonia in the postoperative period of major heart surgery. Chest 2008, 134:938-946.

37. Lacherade JC, De Jonghe B, Guezennec P, Debbat K, Hayon J, Monsel A, Fangio P, Appere de Vecchi C, Ramaut C, Outin H, Bastuji-Garin S: Intermittent subglottic secretion drainage and ventilator-associated pneumonia: a multicenter trial. Am J Respir Crit Care Med 2010, 182:910-917.

38. Dezfulian C, Shojania K, Collard HR, Kim HM, Matthay MA, Saint S: Subglottic secretion drainage for preventing ventilator-associated pneumonia: a meta-analysis. Am J Med 2005, 118:11-18.

39. NHS and Department of Health care bundle to reduce ventilator associated pneumonia [http://www.clean-safe-care.nhs.uk/Documents/ HII__-_Ventilator_associated_pneumonia.pdf ]

40. Gentile MA, Siobal MS: Are specialized endotracheal tubes and heat-andmoisture exchangers cost-effective in preventing ventilator associated pneumonia? Respir Care 2010, 55:184-196; discussion 196-187.

41. Girou E, Buu-Hoi A, Stephan F, Novara A, Gutmann L, Safar M, Fagon J-Y: Airway colonisation in long-term mechanically ventilated patients. Effect of semi-recumbent position and continuous subglottic suctioning. Intensive Care Med 2004, 30:225-233.

42. Dragoumanis CK, Vretzakis GI, Papaioannou VE, Didilis VN, Vogiatzaki TD, Pneumatikos IA: Investigating the failure to aspirate subglottic secretions with the Evac endotracheal tube. Anesth Analg 2007, 105:1083-1085, table of contents

43. Berra L, De Marchi L, Panigada M, Yu Z-X, Baccarelli A, Kolobow T: Evaluation of continuous aspiration of subglottic secretion in an in vivo study. Crit Care Med 2004, 32:2071-2078.

44. Gorman S, Adair C, O'Neill F, Goldsmith C, Webb H: Influence of selective decontamination of the digestive tract on microbial biofilm formation on endotracheal tubes from artificially ventilated patients. Eur J Clin Microbiol Infect Dis 1993, 12:9-17.

45. Feldman C, Kassel M, Cantrell J, Kaka S, Morar R, Goolam Mahomed A, Philips $\mathrm{Jl}$ : The presence and sequence of endotracheal tube colonization in patients undergoing mechanical ventilation. Eur Respir J 1999, 13:546-551.

46. Costerton JW, Stewart PS, Greenberg EP: Bacterial biofilms: a common cause of persistent infections. Science 1999, 284:1318-1322.

47. Olson ME, Harmon BG, Kollef MH: Silver-coated endotracheal tubes associated with reduced bacterial burden in the lungs of mechanically ventilated dogs. Chest 2002, 121:863-870

48. Rumbak MJ, Newton M, Truncale T, Schwartz SW, Adams JW, Hazard PB: A prospective, randomized, study comparing early percutaneous dilational tracheotomy to prolonged translaryngeal intubation (delayed tracheotomy) in critically ill medical patients. Crit Care Med 2004, 32:1689-1694

49. Blot F, Similowski T, Trouillet JL, Chardon P, Korach JM, Costa MA, Journois D, Thiéry G, Fartoukh M, Pipien I, Bruder N, Orlikowski D, Tankere F, DurandZaleski I, Auboyer C, Nitenberg G, Holzapfel L, Tenaillon A, Chastre J, Laplanche A: Early tracheotomy versus prolonged endotracheal intubation in unselected severely ill ICU patients. Intensive Care Med 2008, 34:1779-1787.

50. Terragni PP, Antonelli M, Fumagalli R, Faggiano C, Berardino M, Pallavicini FB, Miletto A, Mangione S, Sinardi AU, Pastorelli M, Vivaldi N, Pasetto A, Della Rocca G, Urbino R, Filippini C, Pagano E, Evangelista A, Ciccone G, Mascia L, Ranieri VM: Early vs late tracheotomy for prevention of pneumonia in mechanically ventilated adult ICU patients: a randomized controlled trial. JAMA 2010, 303:1483-1489.

51. Craven DE: Preventing ventilator-associated pneumonia in adults: sowing seeds of change. Chest 2006, 130:251-260.

52. Rello J, Lorente C, Bodí M, Diaz E, Ricart M, Kollef MH: Why do physicians not follow evidence-based guidelines for preventing ventilator-associated pneumonia?: a survey based on the opinions of an international panel of intensivists. Chest 2002, 122:656-661

53. Young PJ, Wyncoll DL: Continuous cuff pressure control and the prevention of ventilator-associated pneumonia. Crit Care Med 2007, 35:2470-2471; author reply 2471.

54. Muscedere JG, Day A, Heyland DK: Mortality, attributable mortality, and clinical events as end points for clinical trials of ventilator-associated pneumonia and hospital-acquired pneumonia. Clin Infect Dis 2010, 51 Suppl 1:S120-125.

55. Torres A, Aznar R, Gatell JM, Jimenez P, Gonzalez J, Ferrer A, Celis R, RodriguezRoisin R: Incidence, risk, and prognosis factors of nosocomial pneumonia in mechanically ventilated patients. Am Rev Respir Dis 1990, 142:523-528.

56. Rello J, Rue M, Jubert P, Muses G, Sonora R, Valles J, Niederman MS: Survival in patients with nosocomial pneumonia: impact of the severity of illness and the etiologic agent. Crit Care Med 1997, 25:1862-1867.

57. Nguile-Makao M, Zahar JR, Français A, Tabah A, Garrouste-Orgeas M, Allaouchiche B, Goldgran-Toledano D, Azoulay E, Adrie C, Jamali S, Clec'h C, Souweine B, Timsit JF: Attributable mortality of ventilator-associated pneumonia: respective impact of main characteristics at ICU admission and VAP onset using conditional logistic regression and multi-state models. Intensive Care Med, 36:781-789.

58. Kollef KE, Schramm GE, Wills AR, Reichley RM, Micek ST, Kollef MH: Predictors of 30-day mortality and hospital costs in patients with ventilatorassociated pneumonia attributed to potentially antibiotic-resistant gramnegative bacteria. Chest 2008, 134:281-287.

59. Heyland DK, Cook DJ, Griffith L, Keenan SP, Brun-Buisson C: The attributable morbidity and mortality of ventilator-associated pneumonia in the critically ill patient. The Canadian Critical Trials Group. Am J Respir Crit Care Med 1999, 159:1249-1256.

60. Rello J, Ollendorf DA, Oster G, Vera-Llonch M, Bellm L, Redman R, Kollef MH: Epidemiology and outcomes of ventilator-associated pneumonia in a large US database. Chest 2002, 122:2115-2121.

61. Bercault N, Boulain T: Mortality rate attributable to ventilator-associated nosocomial pneumonia in an adult intensive care unit: a prospective case-control study. Crit Care Med 2001, 29:2303-2309.

62. Fagon JY, Chastre J, Hance AJ, Montravers P, Novara A, Gibert C: Nosocomial pneumonia in ventilated patients: a cohort study evaluating attributable mortality and hospital stay. Am J Med 1993, 94:281-288.

63. Nseir S, Di Pompeo C, Soubrier S, Cavestri B, Jozefowicz E, Saulnier F, Durocher A: Impact of ventilator-associated pneumonia on outcome in patients with COPD. Chest 2005, 128:1650-1656.

64. Torres A, Aznar R, Gatell JM, Jiménez P, González J, Ferrer A, Celis R, RodriguezRoisin R: Incidence, risk, and prognosis factors of nosocomial pneumonia in mechanically ventilated patients. Am Rev Respir Dis 1990, 142:523-528.

65. Bauer TT, Ferrer R, Angrill J, Schultze-Werninghaus G, Torres A: Ventilatorassociated pneumonia: incidence, risk factors, and microbiology. Semin Respir Infect 2000, 15:272-279.

66. Troché $\mathrm{G}$, Moine P: Is the duration of mechanical ventilation predictable? Chest 1997, 112:745-751.

67. Seneff MG, Zimmerman JE, Knaus WA, Wagner DP, Draper EA: Predicting the duration of mechanical ventilation. The importance of disease and patient characteristics. Chest 1996, 110:469-479. 
68. Shorr AF, Zilberberg MD, Kollef M: Cost-effectiveness analysis of a silvercoated endotracheal tube to reduce the incidence of ventilator-associated pneumonia. Infect Control Hosp Epidemiol 2009, 30:759-763.

69. Valles J, Blanch L, Respiratorias CE: Subglottic secretions and Sutton's law: a simple and effective approach. Crit Care Med 2008, 36:623-624.

70. Tantipong H, Morkchareonpong C, Jaiyindee S, Thamlikitkul V: Randomized controlled trial and meta-analysis of oral decontamination with $2 \%$ chlorhexidine solution for the prevention of ventilator-associated pneumonia. Infect Control Hosp Epidemiol 2008, 29:131-136.

doi:10.1186/cc10352

Cite this article as: Zolfaghari PS, Wyncoll DLA: The tracheal tube: gateway

to ventilator-associated pneumonia. Critical Care 2011, 15:310. 